\title{
The Determinants of Money-Laundering Behavior in Indonesia
}

\author{
${ }^{* 1}$ Ningtyas, Vita, ${ }^{2}$ Munawar \& ${ }^{3}$ Wahyudi, Setyo \\ ${ }^{* 1}$ Indonesian Financial Transaction Reports and Analysis Center (INTRAC), Jakarta, Indonesia \\ ${ }^{2}$ Faculty of Economic and Business, Universitas Brawijaya, Malang, Indonesia \\ ${ }^{3}$ Faculty of Economic and Business, Universitas Brawijaya, Malang, Indonesia
}

Note: * Indicates corresponding author

\begin{tabular}{|c|c|}
\hline ARTICLE DETAILS & \multirow{4}{*}{$\begin{array}{l}\text { ABSTRACT } \\
\text { Banks nowadays have come with innovations in all of their } \\
\text { operations. For example, creating a banking service is very easy. } \\
\text { It can be done anywhere using only the devices we have. } \\
\text { However, it increases the possible money laundering risk, where } \\
\text { everyone can have as many banking services as they want to do } \\
\text { money laundering. One of the phenomena is the high number of } \\
\text { Suspicious Financial Transaction Reports (LTKM) received by the }\end{array}$} \\
\hline $\begin{array}{l}\text { Article History } \\
\text { Published Online: publisher use } \\
\text { only }\end{array}$ & \\
\hline $\begin{array}{l}\text { Keywords } \\
\text { LTKM, INTRAC, money laundering, } \\
\text { money laundering risk, ordinal } \\
\text { regression analysis. }\end{array}$ & \\
\hline \multirow{3}{*}{$\begin{array}{l}\text { "Corresponding Author } \\
\text { Email: vitafauziahningtyas@gmail.com }\end{array}$} & \\
\hline & $\begin{array}{l}\text { Indonesian Financial Transaction Reports and Analysis Center } \\
\text { (INTRAC). Hence, this study analyzes the effect of Indonesia's } \\
\text { social demography on each individual's risk of committing money } \\
\text { laundering. }\end{array}$ \\
\hline & $\begin{array}{l}\text { Using secondary data obtained from INTRAC, the derived and } \\
\text { selected independent variables were analyzed using ordinal } \\
\text { logistic regression to determine their effect on the dependent } \\
\text { variable, i.e., the Money Laundering Risk Score (MLRS). This } \\
\text { study finds that the social demographic factors affecting the money } \\
\text { laundering risk committed by individuals are sex, age, marital } \\
\text { status, occupation, and the history of financial service usage, in } \\
\text { which occupation has the highest effect }\end{array}$ \\
\hline
\end{tabular}

\section{Introduction}

At this time, money circulation can happen anywhere easily. Money transfer can be done quickly and easily around the world. It is a form of financial transaction activity. One of the risks that may occur in financial transactions is money laundering. Money Laundering is the action that is carried out to disguise the origin of money proceeds acts of crime or money illegally for the sake of generating a profit for individuals or groups who commit acts of crime (INTRAC, 2017).

Money Laundering is detrimental to the state because it can affect or undermine the economy's stability nationwide with the increasing number of crimes (Tanya, 2010). Money Laundering affects the economic macro of a country. It is caused by shadow economic

Faculty of Economics and Business,

Brawijaya University activities, criminal activities, the illicit flow of funds, and tax evasion. The shadow economy involves legal activities but ignores tax payments. In other words, tax evasion occurs. When tax evasion is higher, a more significant collection of funds triggers money laundering. Therefore, the flow of illegal funds triggers the occurrence of money laundering because the purpose of these activities is to cover up illegal funds as if they were legal (Hendriyetty \& Grewal, 2017).

Indonesian Financial Transaction Reports and Analysis Center (INTRAC) is held accountable for Money Laundering in Indonesia. One of the tasks INTRAC is receiving reports and analyzing the action, which refers to acts of Anti-Money Laundering or AML (Law of The Republic of Indonesia Number 8 Year 2010 Concerning The Prevention and Eradication of the Criminal Act of Money Laundering). INTRAC 
receives reports from the reported parties regarding suspicious financial transactions that indicate money laundering. These reports are called Laporan Transaksi Keuangan Mencurigakan (Suspicious Financial Transactions Report) or LTKM.

From 2016 to 2020, the LTKM data shows that the number of reports declined compared to the previous year. It can be seen from Picture 1. Based on Picture 1, LTKM in Indonesia has increased until 2019, then decreased in 2020. Therefore, money laundering is essential in minimizing the adverse effects on a country's economy, especially in Indonesia. Money laundering is a real problem for banking institutions and the nation. It is a source of crime because, without money laundering, criminals cannot hide their dirty money and claim it as clean. Based on the results of this study, it appears that the level of money laundering risk strongly influences banking institutions. Frontline officers in banking institutions must be aware of their enormous responsibility in money laundering risk assessments (Isa et al., 2015). It is as explained in the results of the Risk Assessment of Money Laundering (TPPU) and Terrorism Financing (TPPT) in the financial services sector by the OJK that the financial services with the highest risk are banking services (OJK, 2019).

Previous research has been explained that several factors influence the risk of money laundering. These factors are age, education level, and the amount of money that influences Vietnam's money laundering risk score $(\mathrm{Ba}$ \& Huynh, 2018). While other studies mention factors such as type of business, occupation, length of use of financial services, history of using financial services, the volume of cash and transfer activities, total volume, domicile, or area of residence also affect the money laundering risk (Price, 2008).

Research on the money laundering risk is fascinating, and still, not many have raised it. However, a study has not discussed related factors of internal individuals that affect the money laundering risk in Indonesia. Some studies only discuss one internal factor of an individual, namely education. Other research mentions several other factors besides education, such as age, the group payroll, and market finance knowledge. However, the respondents in that research were only 120 individuals. It is less representative of all individuals in Vietnam (Ba \& Huynh, 2018). Therefore, in this study, individuals with a larger sample will be discussed to represent the entire population of Indonesia. With individual internal factors such as age, gender, marital status, education, type of work, and area of residence.
This research aims to calculate and describe the money laundering risk on the Indonesian people as well as to determine the influence of factors such as gender, age level, type of education, type of work, and use of banking services on the magnitude of the money laundering risk; and which factors play the most role in increasing the money laundering risk.

\section{Literature Review}

According to the Financial Action Task Force (FATF), which is a task force that oversees all money laundering issues in the world, money laundering is the processing of the proceeds of criminal acts to disguise their illegal origin in order to generate profits for individuals or groups who commit crimes (Ristanti \& Handoyo, 2017). Based on the guidebook published by the IMF (2011), namely The Fund Staff's Approach to Conducting National Money Laundering or Financing of Terrorism Risk Assessment, it explains that risk is $R=[(T)+(V)]$ $x(C)$, where $T$ is threat, $V$ is vulnerability, and $C$ is consequence.

Risk $=[$ Threat + Vulnerability $] \times$ consequence (IMF, 2011)

A threat is a group of people/objects/activities that have the potential to cause loss, especially in money laundering, which poses a threat, namely criminal acts, terrorist groups, and their finances. At the same time, the vulnerability in question is the weakness of the existing system in money laundering or acts of terrorism. Maybe a product or service finances makes it easier to act laundering money or financing terrorism. Its final consequences are damages that occur due to laundering money/funding of terrorism against all of the economic and social aspects that are more extensive (FATF, 2012).

The risk factors for money laundering consist of internal, external, or calculated factors. The availability and form of data that can be used by Anti-Money Laundering (AML) Risk Management determines which categories are included in the risk factors. Risk factors that require a formula calculation based on available data are referred to as calculated risk factors. Examples include the average or total cash volume during a specific period, the average or total volume mentioned above during a specific period, and the total volume of activity during a specific period (Price, 2008).

In 2017 OJK has conducted an assessment of money laundering offenses in the Financial Services sector. In this book, the risk is classified into four sectors: banking, securities companies, investment managers, and 
insurance. The conclusion obtained is that customer profiles with occupational groups of government officials, entrepreneurs, political and corporate administrators have a high risk of committing money laundering. Fund transfers, priority services, safe deposit boxes, and correspondent banking are the types of high-risk products. DKI Jakarta, East Java, West Java, North Sumatra, Banten, and Central Java are the provinces most at money laundering risk in the geographic area category. Lastly, the riskiest means of money laundering is the Cash Deposit Machine (CDM) distribution channel (INTRAC, 2017).

Furthermore, in 2019 OJK re-published the same book with the title Risk Assessment of $\mathrm{ML}$ and TF in the financial services sector. This time, OJK collaborated with INTRAC in compiling the book. In this book, the conclusions obtained are slightly different from the previous books. In the customer profile category, from the previous four groups with high risk to eight groups having a high risk of committing money laundering acts. These groups are government officials, entrepreneurs, political party administrators, corporations, TNI and Polri (including retirees), civil servants (including retirees), BUMN/BUMD management, and professionals (INTRAC, 2019).

So it can be concluded that several factors can influence the money laundering risk assessment. These internal and external factors may differ from one country to another. Because this study will look at the risk to an individual, in this study the factors that will be used in assessing whether a person is at high or low risk in committing money laundering are the area of residence, occupation, users of financial services, and how long they use financial services.

As previously mentioned, geography or the area where a person lives, the type of customer (here we will use the profession of work), and the products or services offered are things that must be considered in compiling the money laundering risk that someone can carry out. It is supported by the results of the National Risk Assessment issued by the Financial Services Authority, as previously mentioned. (Price, 2008).

Financial Action Task Force or FATF, which acts as a regulator in the fight against laundering money in the world, put forward in a report that called that the factors which affect the level of money laundering risk with relations business include several things, namely the risk of the customer, the risk of the country or geographical, and the risk of product or financial instruments. According to the report of the one of which is the risk a customer is Political
Exposed Person (PEP) and officials of the public. What is meant by PEP here are people who are in contact with politics in their country. PEP status was itself does not always mean that a person involved in corruption. It happens because a PEP is a person with a money laundering risk, which is sustainable both foreign and domestic. PEP risk is higher because it can significantly influence the private sector business's decision or access to the accounts and state funds. Because of that, a PEP shall be monitored in particular related to the customers and the transactions (FATF, 2012). In Indonesia alone, it has been run through the Commission, which issued a mandatory report to the PEP and Officials of Public are periodically in the Report Results Wealth Officials State (LHKPN).

Furthermore, the FATF has realized that particular products, services, transactions, or channel delivery can pose a significant money laundering risk. For example, in banking, transactions anonymously including money transactions in cash, relationship or transaction of business online, and payments were received from the three that are not known or unrelated. For example, an official public that corrupt using techniques Money Laundering is similar to that used by criminals organized to hide the proceeds of corruption. For example, the use of money in cash, transfer wire, or the formation of companies shells and account trusteeship is present in almost all corruption cases great recently. In the context of business bribery, the use of intermediaries often arises. Besides that, various kinds of products and services are offered by institutions finance has proved susceptible to abuse by PEP. As private banking, product banking retail, account correspondent and concentration, transactions with accounts of companies non-client, and the transfer wire. (FATF, 2012)

Laundering money has been much studied in the previous year. One of the essential requirements for an effective risk-based antimoney-laundering system is communication and information sharing between regulators and those who are regulated. Risks that must be borne by financial institutions to be identified include sources of risk, customer factors, transactions and services that inform risk assessments, and how to mitigate these risks (Ross \& Hannan, 2007). It supports the research that the customer factor is one of the factors that can be used to affect the risk of laundering money may occur.

Furthermore, the factors that influence the spread of laundering money are infrastructure, education, institutions, the integrity of the system of government, and innovation. The fifth factor lowers the level of 
activity of laundering money (Vaithilingam \& Nair, 2007). It supports the research in advance that the factors customers, especially education and institutions, influence the occurrence of money laundering. In addition to factors, internal individuals in the study have also concluded that factors external, namely infrastructure no effect against Money Laundering. Infrastructure which referred to the research this is the internet banking. It is because Internet banking has not been widely used in developing countries, so it has a negative effect on money laundering (Vaithilingam \& Nair, 2007).

The following study also concluded that there is an inverse (negative) relationship between employee training and money laundering, where employee training is included in informal education (Usman Kemal, 2014). Furthermore, the following study concluded the same thing: the higher a person's education, the higher their morale and keep them away from criminal activities. That is, getting higher education, then the money laundering risk is low (Reganati \& Oliva, 2018). Both of these studies support previous research that education affects money laundering.

Research subsequent entitled to use the model of regression logistics and data obtained from collective respondents HSBC in Vietnam. The research concluded that there is a negative correlation between the money laundering risk and groups of salary and academic level. It is demonstrated that even lower amount of money obtained by the respondent and the increasingly low level of academic they then increasingly high money laundering risk that happens. In addition to the group, aged respondents were higher will lead to the money laundering risk that is high occurred in market finance. When a person with age is older, they will have more experience and knowledge of the financial and banking market to implement some of the activities of criminals, especially Money Laundering Risk. (Ba \& Huynh, 2018).

Furthermore, in Indonesia alone, on a bulletin statistics were presented by INTRAC in the year 2017, the types of sex both men and women have an index that almost equal to the understanding of $A M L$, and both experienced a rise from the year 2016 compared to the year 2017. Next, based on the group age population, groupage are more high have ratings that are not much good against AML compared groups of age are much lower. Meanwhile, according to the level of education, the public with the level of education that low tends to have a perception is not much better against acts of criminal laundering money than people educated high. And based on the type of work, there is no difference in the perception of money laundering

Faculty of Economics and Business,

Brawijaya University offenses in terms of public understanding and aspects of evaluating the effectiveness of the performance of the AML regime (INTRAC, 2017) In 2018 INTRAC again conducted the same survey as the previous year. The conclusions resulted from the public's understanding of the tasks and functions of APUPPT increased. At the risk area of understanding, the public is appropriate where comprehension is high in the area or region with a high risk. The risk profile is also appropriate, where the high-risk profile has a higher understanding than the lower risk profile.

Based on gender, age group, and level of education, the results obtained in 2018 are still almost the same as the previous year. However, in 2018, males had a lower understanding of APUPPT than females. Meanwhile, the age group that has the highest understanding of APUPPT is the age group of 24-30 years. Finally, higher education levels have a higher understanding than lower levels of education (INTRAC, 2019).

The level of laundering money in a country is still difficult to measure until this moment. However, it can be seen from the money laundering risk to prevent this. The money laundering risk comes from three factors: internal, external, and calculated (Price, 2008). In the study of this factor that will be studied are factors internal of the individual's own. As described previously, factors internal of an individual to do the Money Laundering can be calculated from the area a place to stay, profile customers, and the history of the use of services financial (Price, 2008). Then the money laundering risk is categorized into several criteria. Meanwhile, according to previous research, a couple of profiles of customers affects the money laundering risk customers are. Profile here is the age, type of sex, status of marriage, level of education, areas of life, and type of work.

\section{Method}

The research is done using the secondary data results of the public perception survey conducted by INTRAC in 2018. The target sample in the survey was one of the people in a household aged 17 years to above. The sample frame for the National Survey consists of 11,040 individual samples spread over 1,104 villages/wards in 173 regencies/cities in 34 provinces. The list of villages/wards which become sample locations for households in this National Survey can be seen in the appendix. In each village/ward, ten households were selected randomly by considering the availability of household members aged 17 . It was done so that all villages and wards in Indonesia could be 
represented from that ten households. (INTRAC, 2019)

In this research, to see the data and then make some adjustments related to this Money Laundering Risk (MLR) will be calculated as follows in table 1 . Then based on table 1 , the model established in this research is the Money Laundering Risk Score (MLRS), which can be defined as follows :

MLRS $=20 \%$ Area weight $+40 \%$ work risk weight $+40 \%$ weight of duration of use of financial services.

The financial services that are focused on in this research are banking financial services, which according to the risk assessment results by the FSA, occupy the largest number in Indonesia. The Independent variables used in Table 2 are age, gender, the status of marriage, education, type of work, the area where they live, and the use of financial services.

Based on the chosen variables, this research uses analysis regression multiple to measure the relationship between the money laundering risk on each individual with the determinant. The model used is as follows :

\section{MLRS $=\alpha+\beta 1 \mathrm{JK}+\beta 2 \mathrm{Age}+\beta 3 \mathrm{Edu}+\beta 4 \mathrm{MAR}+$ $\beta 5 \mathrm{JOB}+\beta 6 \mathrm{PJ}+\beta 7 \mathrm{LPJ}+\beta 8 \mathrm{TT}+\beta 9 \mathrm{WIL}$}

\author{
Where : \\ MLRS = Money Laundering Risk Score \\ JK = Gender \\ Age = Age Group \\ Education $=$ The highest education \\ completed by the respondent \\ MAR = Marital status \\ $\mathrm{JOB}=$ Type of Job \\ PJ = Financial Service User \\ LPJ $\quad$ period of using Financial \\ Services \\ ST = village or city residence \\ WIL = area of residence (province)
}

In addition to using Logistics Regression Analysis, Multinomial Regression Analysis was also used in scoring dependent variables, as in Table 3. In addition, the Partial Test/G Test will also be used to test the effect of independent variables to dependent variables together or simultaneously in the Logistics Multinomial Regression. The Partial Test is used to determine the effect of independent variables, which does have the effect of significantly against the dependent variables and Goodness of fit or the feasibility of a regression model from the coefficient of determination (R2).

\section{Result and Discussion}

Faculty of Economics and Business, Brawijaya University
Table 4 shows that the number of samples used in the study is 11,040 samples, consisting of 173 Regency/City in 34 provinces, with minimum and maximum value as well as the mean and standard deviation for each variable that is used in this research. This research used Age Group (Age), Gender (JK), Education (Edu), having a Bank Account (PJ), how long used the banking service (LPJ), the category of risk area (WIL), the status of marriage (MAR), residence (TT), and the risk category of the work (JOB) as variables, where these variables are predictor variables to examine the Money Laundering Risk Score (MLRS) that an individual may carry.

The results of multiple regression can be seen in the attached table 5 . Results of ordinal logistic regression are obtained by choosing the MLRS variable in the form of order as has been described in the previous chapter as a variable dependent. Where in the ordinal logistic regression, compared independent variables are always two groups, namely the first group worth one and the other group worth zero. Based on Table 5, the estimation results of the analysis of money laundering risk in Indonesia are using ordinal logistic regression. Based on the previous regression models, results can be written back into:

Money laundering risk category very low vs low medium high

MLRS $=3,05+\quad 0,78 \quad \mathrm{JK}+0,18$ Age- 0,38

MAR+5,74 JOB+0,04 WIL+1,36 PJ+0,10 LPJ

That is MLRS (very low) are zero and MLRS (low, medium, and high) is worth one

Money laundering risk category is very low, low vs medium high

MLRS $=1,21+0,78 \quad \mathrm{JK}+0,18$ Age-0,38 MAR+5,74 JOB+0,04 WIL+1,36 PJ+0,10 LPJ

This means that MLRS (very low and low) is zero and MLRS (medium, and high) is one.

Money laundering risk category is very low, low medium vs high

MLRS $=2,04+\quad 0,78 \quad \mathrm{JK}+0,18$ Age- 0,38 MAR+5,74 JOB+0,04 WIL+1,36 PJ+0,10 LPJ

This means that MLRS (very low, low, and medium) is zero and MLRS (high) is one.

From the three models above, it can be seen that the male gender has a positive effect on the money laundering risk, where men are more at money laundering risk than women by 0.78 units. The age variable has a positive effect on the dependent variable, where the higher the age of an individual, the higher the money laundering risk. It means that as a person's age increases, the money laundering risk increases.

The job variable (JOB) also positively 
influences money laundering, the same as in the analysis results with the previous method. Where jobs with high risk have a higher money laundering risk than jobs with low or medium categories, the money laundering risk will increase by 5.74 units in line with the increase in job risk. Likewise, the residence variable is also positive.

The service user variable (PJ) has a positive effect, meaning that if an individual has a bank account or becomes a user of banking services, that person has a higher money laundering risk. Likewise, the old variable using financial services (LPJ) also has a positive influence, meaning that the longer someone uses financial services, the money laundering risk will decrease. It is due to the categorization made earlier that the longer a person uses financial services, the lower the money laundering risk.

The education variable produces different things from the results of previous studies. By using the order logit method and multiple regression analysis, the education variable does not affect the money laundering risk in Indonesia. It is contrary to the results of several previous studies by Vaithilingam \& Nair (2007), Usman Kemal (2014), Reganati \& Oliva (2018), and Tran, Huynh H B (2018). The higher a person's education, the lower the risk of that person laundering money. In Indonesia, it can be concluded that education does not affect the $r$ money laundering risk that may occur. It can be seen in Table 6 that for risk jobs in higher education, the majority of the lots are in high school or equivalent. It can also be seen that there are differences in the amount of which is very large between the level of education that exists. For example, the number of respondents is small for Magister education. It affects the results of the analysis obtained, which is considerable. In other words, in Indonesia, education does not guarantee or affect a person in laundering money.

Based on the results above, of the nine variables used, two variables have no effect, namely the education variable and the place of residence. It is the same as the results obtained using the previous analysis. These two variables do not affect an individual at money laundering risk.

In addition, each result is obtained from the upper margin value of each variable, as shown in Table 7 below. From table 7, it can be seen that assuming the average of all independent variables is used, the chance of an individual having a very low money laundering risk is $0 \%$. Meanwhile, for low risk is $4.78 \%$, moderate risk is $94.87 \%$, and high risk is $0.3 \%$.

Testing the significance of the model as a whole is done through Likelihood-Ratio (LR) to

Faculty of Economics and Business,

Brawijaya University determine the effect of variable characteristics of individuals are simultaneously in influencing the money laundering risk in Indonesia. Based on the results of the $G$ test obtained values of $L R$ chi2 (9) at 15045.12 with a value $p$-value of $0.0000>0.05$. With so, $\mathrm{HO}$ is rejected, meaning that the independent variables have an effect on the dependent variable.

The Goodness of Fit test results on the research shows that Pseudo R2 is 0.7148 . It is indicated that the independent variables able to explain the dependent variable amounted to 71.48 percent. In other words, 71.48 percent of the variation of the dependent variable can be explained by the model.

\section{Conclusion and Recommendation}

From the research results obtained, it can be concluded that :

1. Several individual characteristics influence the money laundering risk in Indonesia. These factors are gender, age, marital status, occupation, and history of using financial services, which in this study use user status and length of use of financial services.

2. A man is more at money laundering risk, and a higher age and married marital status also increase the money laundering risk that can be carried out. In addition, the risk of work and users and the length of time using financial services also increase the money laundering risk. Education and residence factors have insignificant results, meaning that these two variables do not affect the money laundering risk that may occur. So it cannot be concluded that these two factors have an effect on money laundering, especially in Indonesia. For other factors, namely gender, age, type of work, and users of financial services, these four factors have a positive effect on the money laundering risk. The next factor is that the length of time using financial services has the opposite effect, meaning that the higher education and duration of using financial services, the lower the money laundering risk.

3. The most influential factor in the money laundering risk is the occupational risk factor. When job risk increases, an individual is at higher money laundering risk. We recommended that INTRAC use these results in carrying out their duties, which in processing the data received can prioritize individuals with the criteria that have been concluded. Financial service institutions as reporting parties also need to be more careful in accepting new customers and immediately report to 
INTRAC if there are accounts with more risky criteria and have unfair transactions.

Based on the results, it was found that men are more at money laundering risk as well as jobs with higher risk, higher age, and areas of residence with high risk are also at higher money laundering risk. The history of an individual in using financial services is also influential, where a new individual who uses these financial services is more at money laundering risk. In addition, in this study, because what is discussed is only individual behavior in using banking financial services, to complete this research, it is necessary to conduct further research on the use of other financial services such as investment, insurance, or financing. In addition, it can also add other variables, such as income and the finances of each individual.

Table 1. The weighting of risk factors based on the Money Laundering Risk variable

\begin{tabular}{|c|c|c|c|}
\hline $\begin{array}{c}\text { Risk } \\
\text { Factors }\end{array}$ & Weight & Result & Score \\
\hline \multirow{3}{*}{$\begin{array}{l}\text { Area of } \\
\text { residence }\end{array}$} & $20 \%$ & Low & 30 \\
\hline & $20 \%$ & Medium & 60 \\
\hline & $20 \%$ & High & 100 \\
\hline \multirow[t]{3}{*}{ work } & $40 \%$ & Low & 30 \\
\hline & $40 \%$ & Medium & 60 \\
\hline & $40 \%$ & High & 100 \\
\hline \multirow[t]{4}{*}{$\begin{array}{l}\text { service use } \\
\text { period }\end{array}$} & $40 \%$ & $\begin{array}{c}>10 \\
\text { years }\end{array}$ & 25 \\
\hline & $40 \%$ & $\begin{array}{c}6-10 \\
\text { years }\end{array}$ & 50 \\
\hline & $40 \%$ & $\begin{array}{c}1-5 \\
\text { years }\end{array}$ & 75 \\
\hline & $40 \%$ & $<1$ years & 100 \\
\hline \multirow{2}{*}{ PEP } & \multirow{2}{*}{$\begin{array}{l}\text { Political } \\
\text { Exposed } \\
\text { Person }\end{array}$} & $1=$ yes & \multirow{2}{*}{$\begin{array}{l}\text { High Risk } \\
\quad=100\end{array}$} \\
\hline & & $0=$ no & \\
\hline \multirow{4}{*}{$\begin{array}{c}\text { Money } \\
\text { Laundering } \\
\text { Risk Score }\end{array}$} & \multirow{4}{*}{ MLRS } & Very Low & $0-25$ \\
\hline & & Low & $26-50$ \\
\hline & & Medium & $51-75$ \\
\hline & & High & $76-100$ \\
\hline
\end{tabular}

the weighting of several factors in money laundering risk used based on the data used in the study

Table 2. Operational Definition of Independent Variable

\begin{tabular}{|c|c|c|}
\hline $\begin{array}{c}\text { Variable } \\
\text { s }\end{array}$ & Definition & Scale \\
\hline JK & Sex & $\begin{array}{c}1=\text { Man } \\
0=\text { Woman }\end{array}$ \\
\hline Usia & Age & $\begin{array}{c}0=17-30 \text { years } \\
1=31-40 \text { years } \\
2=41-60 \text { years } \\
3=\text { lebih dari } 60 \text { years }\end{array}$ \\
\hline Edu & Education & $\begin{array}{c}\text { Did not finish elementary } \\
\text { school }=0 \\
\text { Elementary School }=6 \text { years } \\
\text { Junior High School }=9 \\
\text { Years } \\
\text { High School }=12 \text { Years } \\
\text { D1/D2/D3 }=15 \text { Years } \\
\text { D4/S1 }=16 \text { Years } \\
\text { S2 }=18 \text { Years } \\
\text { S3 }=21 \text { Years }\end{array}$ \\
\hline MAR & Marital Status & $\begin{array}{c}1=\text { Married } \\
0=\text { Unmarried }\end{array}$ \\
\hline \multirow[t]{14}{*}{ JOB } & Low $=0$ & $\begin{array}{c}\text { Board / Employee } \\
\text { Foundation / Institutions } \\
\text { Regulated Law }\end{array}$ \\
\hline & \multirow{5}{*}{ Medium $=1$} & Private employee \\
\hline & & IRT \\
\hline & & Bank Employee \\
\hline & & $\begin{array}{c}\text { Employee Merchants } \\
\text { Exchange Foreign }\end{array}$ \\
\hline & & Student \\
\hline & \multirow[t]{8}{*}{ High $=2$} & $\begin{array}{c}\text { Officials Institute of } \\
\text { Government (Executive, } \\
\text { Legislative and Judiciary) }\end{array}$ \\
\hline & & Entrepreneur \\
\hline & & Political party manager \\
\hline & & Corporation \\
\hline & & PNS(including Retirees) \\
\hline & & BUMN/BUMD employees \\
\hline & & $\begin{array}{c}\text { Civil Servants (including } \\
\text { Retirees) }\end{array}$ \\
\hline & & TNI / Police \\
\hline TT & Residence & $\begin{array}{c}0=\text { Village } \\
1=\text { City }\end{array}$ \\
\hline WIL & $\begin{array}{c}\text { Area of } \\
\text { Residence }\end{array}$ & $\begin{array}{c}\text { Low }=0 \\
\text { Medium }=1 \\
\text { Height }=2\end{array}$ \\
\hline PJ & $\begin{array}{c}\text { Used The } \\
\text { Banking service }\end{array}$ & $\begin{array}{c}1=\text { yes } \\
0=\text { no }\end{array}$ \\
\hline LPJ & $\begin{array}{l}\text { Banking service } \\
\text { use period }\end{array}$ & $\begin{array}{c}3=<\text { from } 1 \text { year } \\
2=1-5 \text { yrs } \\
1=6-10 \text { yrs } \\
0=>10 \text { yrs }\end{array}$ \\
\hline
\end{tabular}

Table 3. Operational Definition of Dependent Variable

Faculty of Economics and Business, 


\begin{tabular}{|c|c|}
\hline Variables (Y) & Description \\
\hline $0=$ Very Low risk MLRS & $\begin{array}{c}\text { If the MLR is worth } 0 \\
\text { up to } 25\end{array}$ \\
\hline $1=$ Low risk MLRS & $\begin{array}{c}\text { If the MLR is worth } 26 \\
\text { up to } 50\end{array}$ \\
\hline $2=$ Medium risk MLRS & $\begin{array}{c}\text { If the MLR is worth } 51 \\
\text { up to } 75\end{array}$ \\
\hline $3=$ High risk MLRS & $\begin{array}{c}\text { If the MLR is worth } \\
75 \text { up to } 100\end{array}$ \\
\hline $\begin{array}{l}\text { Dependent variables categorization is based on the results } \\
\text { of the Money Laundering Risk Score calculation on the data } \\
\text { used }\end{array}$
\end{tabular}

Table 4. Descriptive Statistics

\begin{tabular}{|l|l|l|l|c|c|}
\hline Variable & Obs & Mean & Std. Dev. & Min & Max \\
\hline usia & 11,040 & 2.132 .971 & 1.101 .959 & 0 & 4 \\
\hline JK & 11,040 & .5929348 & .4913095 & 0 & 1 \\
\hline Pend & 11,040 & 1.260 .752 & 2.999 .205 & 0 & 21 \\
\hline PJ & 11,040 & .796558 & .4025768 & 0 & 1 \\
\hline LPJ & 11,040 & .7959239 & .9328004 & 0 & 3 \\
\hline wil & 11,040 & 1.501 .812 & .7566455 & 0 & 2 \\
\hline MAR & 11,040 & .7802536 & .4140935 & 0 & 1 \\
\hline TT & 11,040 & .4166667 & .493029 & 0 & 1 \\
\hline \multicolumn{7}{|l|}{ work } & 11,040 & .9527174 & .8877236 & 0 & 2 \\
\hline \multicolumn{7}{|c|}{ Descriptive Statistics of independent variables } \\
\hline
\end{tabular}

Table 5. Analysis Results

\begin{tabular}{|c|c|c|c|c|}
\hline \multirow{2}{*}{$\begin{array}{c}\text { Depende } \\
\text { nt } \\
\text { Variable } \\
\text { MLRS } \\
\end{array}$} & \multicolumn{2}{|c|}{ OLS (Numeric MLRS) } & \multicolumn{2}{|c|}{$\begin{array}{c}\text { Ordinal Logit (MLRS } \\
\text { order) }\end{array}$} \\
\hline & Coefficient & $\begin{array}{l}\text { Standar } \\
\text { d Error }\end{array}$ & Coefficient & $\begin{array}{l}\text { Standar } \\
\text { d Error }\end{array}$ \\
\hline $\mathrm{JK}$ & $3,277353^{\star * *}$ & 0.000 & $\underset{* *}{0,7813887^{*}}$ & 0.000 \\
\hline Age & $\underset{* *}{0,3007353^{*}}$ & 0.000 & $\underset{* *}{0,1812174^{*}}$ & 0.000 \\
\hline Edu & $-0,9983629$ & 0.425 & $-0,1740484$ & 0.709 \\
\hline MAR & $\overline{-}^{1,649153^{* * *}}$ & 0.000 & $\underset{* \star}{-}$ & 0.000 \\
\hline JOB & $2,084548^{* * *}$ & 0.000 & $5,739968^{\star * *}$ & 0.000 \\
\hline TT & 0,0563144 & 0.737 & 0,0563144 & 0.475 \\
\hline WIL & $1,51626^{\star \star \star}$ & 0.006 & $\underset{* *}{0,0416008^{*}}$ & 0.000 \\
\hline PJ & $\begin{array}{c}- \\
0,5938589^{*}\end{array}$ & 0.053 & $1,362173^{\star * *}$ & 0.000 \\
\hline LPJ & $\underset{* \star}{0,3615919^{*}}$ & 0.000 & $\underset{* \star}{0,1038929 *}$ & 0.000 \\
\hline _cons & $1,658957^{* * *}$ & 0.000 & 3,058274 & \\
\hline _cons & - & - & 1,215304 & \\
\hline _cons & - & - & 2,046254 & \\
\hline
\end{tabular}

Faculty of Economics and Business, Brawijaya University
Table 6. The statistical description of Education and Employment Data

\begin{tabular}{|c|c|c|c|c|}
\hline \multirow{2}{*}{ Education } & \multicolumn{3}{|c|}{ Risk factor of work } & \multirow{2}{*}{ Total } \\
\cline { 2 - 4 } & Low & Medium & High & \\
\hline Doctor & 1 & 3 & 2 & 6 \\
\hline Magister & 28 & 126 & 59 & 213 \\
\hline Bachelor Degree & 575 & 1,630 & 554 & 2,759 \\
\hline DI/DII/DIII & 288 & 486 & 133 & 907 \\
\hline High School & 2,103 & 1,911 & 1,190 & 5,204 \\
\hline Junior High School & 629 & 352 & 223 & 1,204 \\
\hline Elementary School & 358 & 202 & 139 & 699 \\
\hline $\begin{array}{c}\text { Did not finish } \\
\text { elementary school/ } \\
\text { equivalent }\end{array}$ & 28 & 12 & 8 & 48 \\
\hline
\end{tabular}

Table 7. Definitions Operational of Dependent Variables

\begin{tabular}{|c|c|c|c|c|}
\hline $\begin{array}{c}\text { MLRS } \\
\text { Category }\end{array}$ & Margin & $\begin{array}{c}\text { Delta- } \\
\text { methodStd. } \\
\text { Err. }\end{array}$ & $z$ & $P>|z|$ \\
\hline Very Low & $9.78 \mathrm{e}-06$ & $1.91 \mathrm{e}-06$ & 5.12 & 0.000 \\
\hline Low & .0478815 & .0032698 & 14.64 & 0.000 \\
\hline Moderate & .9487365 & .0035204 & 269.49 & 0.000 \\
\hline High & .0033722 & .0003502 & 9.63 & 0.000 \\
\hline
\end{tabular}

Picture 1

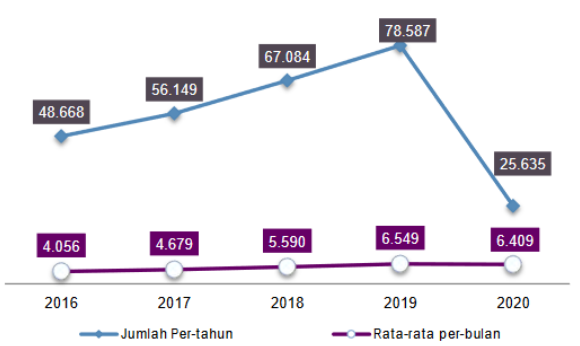

Picture 1. Development of the Number of Suspicious Financial Transaction Reports (LTKM) in Indonesia for 2016-2020

Source: INTRACT (2020)

\section{REFERENCES}

Ba, H., \& Huynh, T. (2018). Money laundering risk from emerging markets: the case of Vietnam. Journal of Money Laundering Control, 21(3), 385-401. https://doi.org/10.1108/JMLC-09-2017- 
0050

FATF. (2012). Specific Risk Factors in Laundering the Proceeds of Corruption: Assistance to Reporting Institutions. June. www.fatf-gafi.org

Hendriyetty, N., \& Grewal, B. S. (2017). Macroeconomics of money laundering: Effects and measurements. Journal of Financial Crime, 24(1), 65-81. https://doi.org/10.1108/JFC-01-2016-0004

IMF. (2011a). Anti-money laundering and combating the financing of terrorism. Siteresources.Worldbank.Org, 80. http://siteresources.worldbank.org/INTAM L/2651971135187891284/20766138/GPD_Booklet_ eap_111202.pdf

IMF. (2011b). The International Monetary Fund Staffs ML/FT NRA Methodology (Issue $\mathrm{Ml})$.

Isa, Y. M., Sanusi, Z. M., Haniff, M. N., \& Barnes, P. A. (2015). Money Laundering Risk: From the Bankers' and Regulators' Perspectives. Procedia Economics and Finance, 28(April), 7-13. https://doi.org/10.1016/s22125671(15)01075-8

OJK. (2019). Updated Indonesia's Risk Assessment on Final Report.

PPATK. (2017). Indeks Persepsi Publik Indonesia Terhadap Tindak Pidana Pencucian Uang \& Tindak Pidana Pendanaan Terrorisme.

PPATK. (2019). IPP APU-PPT. In PPATK (Vol. 44, Issue 8). https://doi.org/10.1088/1751$8113 / 44 / 8 / 085201$

Price, C. (2008). Customer Risk Assessment. Metavante White Paper, 8.

Reganati, F., \& Oliva, M. (2018). Determinants of money laundering: evidence from Italian regions. Journal of Money Laundering Control, 21(3), 402-413. https://doi.org/10.1108/JMLC-09-20170052

Ristanti, Y. D., \& Handoyo, E. (2017). UndangUndang Otonomi Daerah Dan Pembangunan Ekonomi Daerah. Jurnal Riset Akutansi Keuangan, 2(2), 115-122.

Ross, S., \& Hannan, M. (2007). Money laundering regulation and risk\&hyphen; based decision\&hyphen; making. Journal of Money Laundering Control, 10(1), 106115.

https://doi.org/10.1108/136852007107218 90

Tanya, B. L. (2010). Pencucian Uang (Money Laundering) Dan Dampaknya Dalam Pembangunan Ekonomi. 1-30.

Undang-Undang Republik Indonesia Nomor 8 Tahun 2010, 1 (2010).
Vaithilingam, S., \& Nair, M. (2007). Factors affecting money laundering: lesson for developing countries. Journal of Money Laundering Control, 10(3), 352-366. https://doi.org/10.1108/136852007107635 06. 